\title{
The 'Factory Manager Dilemma'
}

\section{Purchasing Practices and Environmental Upgrading in Apparel Global Value Chains}

\author{
Khan, Mahwish J; Ponte, Stefano; Lund-Thomsen, Peter
}

Document Version

Accepted author manuscript

Published in:

Environment and Planning A

DOI:

$10.1177 / 0308518 \times 19876945$

Publication date:

2020

License

Unspecified

Citation for published version (APA):

Khan, M. J., Ponte, S., \& Lund-Thomsen, P. (2020). The 'Factory Manager Dilemma': Purchasing Practices and Environmental Upgrading in Apparel Global Value Chains. Environment and Planning A, 52(4), 766-789.

https://doi.org/10.1177/0308518X19876945

Link to publication in CBS Research Portal

\section{General rights}

Copyright and moral rights for the publications made accessible in the public portal are retained by the authors and/or other copyright owners and it is a condition of accessing publications that users recognise and abide by the legal requirements associated with these rights.

\section{Take down policy}

If you believe that this document breaches copyright please contact us (research.lib@cbs.dk) providing details, and we will remove access to the work immediately and investigate your claim. 


\title{
The 'Factory Manager Dilemma': Purchasing Practices and Environmental Upgrading in Apparel Global Value Chains
}

\author{
Mahwish J Khan, Stefano Ponte, and Peter Lund-Thomsen
}

Journal article (Accepted manuscript*)

\section{Please cite this article as:}

Khan, M. J., Ponte, S., \& Lund-Thomsen, P. (20२०). The 'Factory Manager Dilemma': Purchasing Practices and Environmental Upgrading in Apparel Global Value Chains. Environment and Planning A, 5244), 766-789. https://doi.org/10.1177/0308518K19876945

DOI: https://doi.org/10.1177/0308518X19876945

Copyright (C) The Author(s) २०२०. Reprinted by permission of SAGE Publications.

* This version of the article has been accepted for publication and undergone full peer review but has not been through the copyediting, typesetting, pagination and proofreading process, which may lead to differences between this version and the publisher's final version AKA Version of Record. 


\section{THE 'FACTORY MANAGER DILEMMA': PURCHASING PRACTICES AND ENVIRONMENTAL UPGRADING IN APPAREL GLOBAL VALUE CHAINS}

Mahwish J. Khan, Assistant Professor, Faculty of Business Administration, Iqra University, Pakistan mahwish@iqraisb.edu.pk

* Stefano Ponte, Professor, Department of Management, Society and Communication, Copenhagen Business School, Denmark spo@msc.dk

Peter Lund-Thomsen, Professor, Department of Management, Society and Communication, Copenhagen Business School, Denmark pl@msc.dk

* corresponding author 


\title{
THE 'FACTORY MANAGER DILEMMA': PURCHASING PRACTICES AND ENVIRONMENTAL UPGRADING IN APPAREL GLOBAL VALUE CHAINS
}

\begin{abstract}
Economic and environmental upgrading in global value chains are inter-twined processes. The existing global value chain literature has so far articulated the relationships between economic and social upgrading but has only recently started to explore the challenges of environmental upgrading from the perspective of suppliers in the Global South. In this article, we examine 'the factory manager dilemma' as a way of conceptualizing the purchasing practices and environmental upgrading requirements faced by suppliers in their dealings with lead firms in global value chains. Specifically, we analyze the environmental upgrading challenges experienced by Pakistani apparel firms. We conclude that Pakistani apparel suppliers are required to both absorb the consequences of global buyers' unsustainable purchasing practices and reduce their own profitability - all in the name of sustainability.
\end{abstract}

Keywords: environmental upgrading, global value chains, buyer-supplier relationships, factory manager dilemma, apparel industry, Pakistan 


\section{Introduction}

Sustainability concerns have become an integral part of the transformation of global production networks and international trade in the new millennium (Khattak and Pinto, 2018). In this context, Global Value Chain (GVC) analysis provides a useful framework to explain these dynamics and how they relate to the evolving role of 'global buyers', to the distribution of gains over time, along value chains and in different localities, and to changes in efficiency and competition among suppliers in the Global South. GVC research addresses sustainability concerns explicitly through its discussion of economic upgrading, social upgrading and environmental upgrading (Posthuma, 2010; Krishnan, 2017a). Although a great deal of attention has been paid to different typologies and trajectories of upgrading (Ponte, 2019), in this article we provide novel contributions on three key issues that still need further analytical development and empirical testing: (1) the tensions that suppliers, especially in the Global South, face between meeting social and environmental upgrading and the everyday sourcing practices of global buyers; (2) the distinction between upgrading as process and upgrading as outcome; and (3) the fallacy of composition in upgrading.

First, we argue that it is of outmost importance to pay attention to the everyday sourcing practices and how these often undermine the prospects for sustained social and environmental improvements along GVCs and production networks. The purchasing practices of lead firms - promoted by their sourcing departments - can involve squeezing product prices and demands for quick adaptation due to sudden or seasonal changes in demand. Last minute orders, for example, can lead to lower wages, short-term or casual worker contracts, excessive overtime work (Lund-Thomsen \& Lindgreen, 2014; Milberg \& Winkler, 2013), and negative environmental consequences arising from suppliers taking short-cuts, for example when it comes to treating polluted water or securing the occupational 
health and safety of their employees (Goger, 2013; Khattak \& Stringer, 2017; Khattak et al., 2015; Ponte 2019). At the same time, the sustainability departments of lead firms may require suppliers to increase worker wages, provide longer-term contracts and social insurance and/or meet environmental sustainability certifications. This entails that understanding social and environmental upgrading cannot be achieved without considering the need to ensure the financial viability of supplier operations (Khan and Lund-Thomsen, 2011; Goger, 2013). Company managers and supply chain consultants often herald the so-called 'business case for social and environmental upgrading' (Blowfield \& Frynas, 2005), but there are often important trade-offs between financial viability and environmental upgrading, as well as conflicts of interests between buyers, suppliers and workers that cannot easily be aligned through value chain partnerships or buyer-supplier cooperation (Lund-Thomsen and Lindgreen, 2018).

Second, we contend that much of the literature lacks clear distinctions between upgrading as a process (e.g. the strategies adopted and choices made by firms, industries and countries to capture more value in GVCs) and upgrading as an outcome (e.g. the actual achievement of better value addition, profitability or economies of scale/scope) (Bair, 2009; Brewer, 2011). While it is important to understand the trajectories that lead to certain outcomes, upgrading as a process should not be seen as an end on its own. As a result, it is important to clarify who benefits from upgrading and in what ways. Tokatli (2012), for example, suggests analyzing redistribution of competences, risks and responsibilities - such as the capacity of firms to profit and accumulate capital, and the capacity of workers to obtain higher wages and better working conditions. Although supplier firms may be successful in economic upgrading, workers in these firms may be suffering from more casual forms of employment and may be subject to increased pollution (Lund-Thomsen, 2004; Barrientos, 2019). As a result, we respond to calls for longer-term considerations of upgrading trajectories in order to assess 
possible risks, benefits and negative impacts affecting different firms, ecologies, social groups and countries (Brewer 2011; Glückler and Paintz, 2016; Ponte 2019).

Third, we observe that a fallacy of composition can affect suppliers in many GVCs, as they 'face enormous competitive pressure from other suppliers to keep costs low, keep quality consistently high, and to keep delivering to buyers on schedule or risk losing the contract' (Milberg and Winkler, 2013: 279). Firms competing for contracts often have to upgrade simply to maintain their position, let alone improve it. Early movers can draw benefits from upgrading, as well as those who can upgrade in situations where few other can. But if most or all suppliers do the same, competitive pressure will have a squeezing effect on prices. In other words, upgraded suppliers may subsequently have to carry out further efforts without necessarily reaping additional benefits beyond their continued participation, and new suppliers will simply have to upgrade to enter the GVC.

In this article, we place the concerns and perspectives of suppliers in the Global South (along with Nadvi and Raj-Reichert, 2015; Raj-Reichert, 2013) at the centre of understanding drivers, processes and economic outcomes of environmental upgrading in GVCs and production networks. We focus in particular on what we call the 'factory manager dilemma' - the dual pressure on suppliers to deliver environmental upgrading as well as respond to buyer pressure on prices, seasonal changes in demand, and last-minute changes in orders. Hence, we contribute to the embryonic literature on supplier perspectives on social and environmental upgrading in GVCs (Khan and Lund-Thomsen, 2011; Ruwanpura, 2016).

Empirically, we seek to answer the following question: How are export-oriented apparel manufacturers in Pakistan affected by the purchasing practices and environmental upgrading requirements of their global buyers? We examine the apparel industry in Pakistan, which constitutes $23 \%$ of the total value of the country's exports (Trade Development Authority of 
Pakistan, 2018). Pakistan was amongst the top ten exporters of apparel in the world until 2013, but its position declined to 19th in 2018 (WTO, 2014; International Trade Centre, 2019). Pakistan's main garment exports are cotton-based and include shirts, trousers, shorts, T-shirts, cardigans, jerseys and pullovers (Khawar et al., 2019). The top three importers of Pakistan's apparel are the European Union (EU), the United States (US) and the United Arab Emirates (UAE) (Trade Development Authority of Pakistan, 2018).

We draw from a non-experimental case study design and utilize material collected through personal interviews, secondary documents and observation. A dyadic analytical approach is carried out as we consider the views of both suppliers and buyers to formulate an overall picture of buyer-supplier relationships in relation to environmental upgrading. We consider only apparel suppliers listed in the 2014-2015 Export Directory of the Trade Development Authority of Pakistan - the most recent directory available at the time of fieldwork. Interviewed suppliers are all located within the apparel clusters of Karachi, Lahore or Faisalabad, where most apparel exporters are concentrated (Khawar et al., 2019; Ministry of Textile Industry, 2014). Semi-structured in-depth interviews were carried out in three stages. In stage one, one of the authors interviewed senior managers in 21 supplier firms which advertised possessing an environmental certification - seven firms from each industrial cluster (see Table 1). In stage two, interviews were conducted with four lead firms (two from the US and two from the EU), which were identified as key international buyers by the interviewed suppliers. In stage three, officers in relevant institutions within Pakistan, such as sourcing houses and certification bodies, were interviewed to provide further insights on buyer-supplier relationships. A software program (TAMS Analyzer) was used to manage and organize data obtained through these multiple sources. ${ }^{1}$ Through this process, similarities and differences were highlighted and three higher-level analytical categories were identified, relating to drivers, processes and economic outcomes of environmental upgrading. 
[Table 1 here]

The rest of the article is structured as follows. The next two sections present the state of the art on economic, social and environmental upgrading. The following two sections discuss our findings on drivers, processes and economic outcomes of environmental upgrading, followed by a specific discussion of the 'factory manager dilemma'. In the last section, we provide some conclusions and highlight our novel contributions to current discussions on upgrading in GVCs.

\section{Economic and Social Upgrading: A Brief Review}

Until the mid-2000s the GVC and global production network approaches were mainly concerned with exploring unequal power relations in the global economy related to how multinational companies based in the global North governed their networks of suppliers around the world, investigating the economic rents that accrued to different actors through the value chain, and indicating how suppliers in the global South could engage in economic upgrading strategies to strengthen their position in GVCs (Gereffi, Humphrey, \& Sturgeon, 2005; Schmitz, 2006).

From around 2005 onwards, the literature also started to investigate the social upgrading of workers in GVCs, including the effects of corporate codes of conduct and multi-stakeholder standards on labor conditions (see. inter alia, Barrientos \& Smith, 2007; Bernhardt \& Pollak, 2016; Ruwanpura \& Wrigley, 2011), the relationship between economic and social upgrading (see, e.g., Barrientos et al., 2011; Barrientos et al., 2016), and the related 'value capture 
trajectories' (Coe and Yeung, 2015; Yeung and Coe, 2015; Neilson et al., 2018). However, only recently has an embryonic literature begun to look at the question of environmental upgrading in GVCs (see inter alia, Goger, 2013; Khattak \& Stringer, 2017; Khattak et al., 2015; Ponte 2019).

The early literature on economic upgrading showed that lead firms in GVCs are often keen on assisting their suppliers to improve their products ('product upgrading') and production processes ('process upgrading'), but much less willing to let suppliers engage in higher value-added tasks, such as branding and distribution ('functional upgrading'), or the transfer of capabilities from one chain to another ('inter-chain upgrading') (Gereffi, 1999; Schmitz, 2006; Tokatli, 2012). More recent contributions have sought to further widen the typology of economic upgrading beyond these four by adding: whole chain upgrading, a shift of the whole GVC 'towards more demanding segments of a market' (Blažek, 2015:855) possibly as a result of strengthening backward linkages (Morris and Staritz, 2014) and/or better horizontal coordination; and relational upgrading, when firms achieve better positionality in production networks thus improving their 'know-who', in addition to their 'know-how' (Glückler and Panitz, 2016; Krishnan, 2017a; Krishnan, 2017b).

Recent efforts have also attempted to go beyond the discussion of economic upgrading to also examine social upgrading trajectories and the interactions between the two (Barrientos et al., 2011; Barrientos and Visser, 2013; Bernhardt and Pollak, 2016; Coe and Hess, 2013; Gereffi and Lee, 2012; Gereffi and Lee, 2016; Milberg and Winkler, 2013; Pegler, 2015). The definition of social upgrading in this literature is generally drawn from the ILO 'Better Work' framework, and refers to improvements in wages, employment conditions and other social standards. In other words, social upgrading is seen as 'the process of improvement in 
the rights and entitlements of workers as social actors, which enhances the quality of their employment' (Barrientos et al., 2011: 324).

Gereffi and Lee (2016) highlight several possible trajectories of social upgrading: a marketdriven trajectory, when demand for goods produced with higher social standards pushes producers to improve work conditions; a CSR-driven trajectory, when the same process is stimulated by private standards or codes of conduct set by global buyers/retailers (LundThomsen and Lindgreen, 2014; Lund-Thomsen and Nadvi, 2010); a multi-stakeholder path, based on the cooperation of private (business, industry associations, NGOs) and sometimes public actors; a labour-centred trajectory, when workers and their labour unions assert their rights and succeed in promoting social upgrading (O'Rourke, 2006); and a public governance path driven by public regulation (Locke et al., 2013). These paths coexist and interact, sometimes displacing, other times complementing each other. This has led Gereffi and Lee (2016) to call for further research on complementary paths, how they emerge, and how they can facilitate social and economic upgrading in developing countries (see also LundThomsen and Lindgreen, 2018). In general, the social upgrading literature indicates that: corporate codes of conduct and multi-stakeholder standards tend to have some positive effects on reducing occupational health and safety risks for workers, but less impact on workers' rights to freely join trade unions and engage in collective bargaining (LundThomsen \& Lindgreen, 2014); and that local suppliers' economic upgrading did not automatically translate into social upgrading (Barrientos et al., 2016). 


\section{Environmental Upgrading}

The research agenda on upgrading in GVCs has recently moved from the examination of its economic and social components to the consideration of its environmental aspects. A common way of conceptualizing environmental upgrading has been to conceive it as the process of improving or minimizing the environmental impact of GVC operations (including production, processing, distribution, consumption and disposal or recycling) (De Marchi, Di Maria, \& Ponte, 2013), or as 'a process by which actors modify or alter production systems and practices that result in positive (or reduce negative) environmental outcomes' (Khattak et al., 2015; Krishnan, 2017b: 117; see also Krishnan 2017a). In this section, we provide a comprehensive review of the relevant literature by focusing on (1) different strategies and drivers of environmental upgrading; and (2) the economic costs and benefits that suppliers accrue from it. $^{2}$

\subsection{Strategies and Drivers}

The genesis of discussions on environmental upgrading in GVCs goes back to a contribution by Jeppesen and Hansen (2004), who suggested that lead firms engagement in environmental upgrading in GVCs can be distinguished between deep and shallow strategies. 'Deep engagement' takes place when buyers provide substantial technical support and engage hands-on with their suppliers. It is more likely to be employed to drive systemic reductions in the environmental impact of the final product, when standards are not readily available and/or when the supply base does not have the capacity to comply (De Marchi et al., 2013a; 2013b). Transactions are complex and handled through trust, reputation and face-to-face meetings. Actors tend to be mutually dependent on knowledge and skills - with the lead firm usually exerting leadership on environmental knowledge and suppliers leading on technical 
knowledge (De Marchi et al., 2013b). Environmental problems and their solutions are considered on a case-to-case basis and do not necessarily need to fit easy-to-measure metrics. The main tools used by the lead firm are design and product specifications, which enable suppliers to improve their environmental performance even though they may have limited environmental awareness to begin with.

'Shallow engagement' by lead firms in environmental upgrading (Jeppesen and Hansen, 2004) tends to take place when suppliers can meet standards through established third-party certifications and/or have the capacity to comply with in-house protocols of lead firms. In shallow collaboration buyers usually demand a certain standard (e.g. International Organization for Standardization (ISO) 14001 or Forest Stewardship Council certification) but do not meaningfully engage with suppliers and provide limited or no technical or financial support (De Marchi et al., 2013a; 2013b). This strategy seems to be best suited to drive improvements that are linked to production processes and eco-efficiency. Lead firms seek to identify the main environmental impacts to be reduced, decide how to deal with them, and embed such information into standards that suppliers have to comply with (De Marchi et al., 2013b; see also Jeppesen and Hansen, 2004). These standards may affect both the supplier selection process and the relation between lead firms and existing suppliers. A milder form of shallow engagement occurs when there is some degree of hands-on involvement by buyers through monitoring and control, especially when SME suppliers are involved. In this case, buyers tend to engage with suppliers in view of complying with its own internal standard or code of conduct, which is monitored directly through auditing, sometimes accompanied by limited technical support.

The distinction between deep and shallow engagement, however, should not be overstated as lead firms can use different strategies within the same GVC. IKEA provides a clear 
example of how a lead firm may actually combine shallow and deep engagement approaches on a case by case basis. IKEA applies a shallow approach to environmental upgrading when third party certifications are available and/or when suppliers already have the capacity to meet its standards (Jeppesen and Hansen, 2004; De Marchi et al., 2013b). But it also takes a deep approach when suppliers do not have the capacity to comply with its standards. For example, IKEA provided direct support and technical assistance for environmental upgrading to a number of strategic partners, both in Eastern Europe and in China and Southeast Asia. This was made possible because IKEA strategically reduced the number of its suppliers in the 2000s. Two of the key conditions for becoming strategic partners and category leaders are that suppliers sell $60-70 \%$ of their total production to IKEA and that they implement its inhouse standards on quality (QWAY) and sustainability (IWAY) (Ivarsson and Alvstam, 2010; 2011).

Another useful distinction is one between different kinds of drivers of environmental upgrading. 'Internal drivers' refer to the factors that lead firms or suppliers leverage to meet their strategic choices - e.g. they increase efficiency or reduce energy consumption. For example, internal drivers (such as fuel savings) have been the key movers of the (limited) environmental upgrading observed in the shipping industry (Poulsen et al., 2016; 2018). The 'external drivers' of environmental upgrading for both buyers and suppliers can be related to new or changing regulation (see, e.g. Tewari and Pillai, 2005), pressure from civil society and/or to buyer-driven demands (Poulsen et al., 2016). Existing research suggests that environmental upgrading is more likely to happen in GVCs characterized by unipolar governance and where lead firms are consumer-facing companies with higher reputational risks (Golini et al., 2018; Lister et al., 2015; Poulsen et al., 2016; Ponte, 2019). 


\subsection{Economic Outcomes}

The literature suggests that early movers can draw benefits from environmental upgrading, but when most or all firms can do the same, competitive pressure will not have positive outcomes on profitability for suppliers. Goger (2013), for example, examined two factories that were built under strict environmental design and operational standards to supply the British supermarket chain Marks \& Spencer (M\&S), and another eco-factory supplying a different buyer. These factories deliver basic standards of environmental compliance and embed an eco-friendly aesthetic (e.g. workers using green uniforms, green vegetation placed on the factory floor). Some of the common elements of these eco-factories are: green building design, LEED certification, use of solar panels and natural lighting, green power purchasing agreements, rainwater catching infrastructure and water recycling, no waste to landfill, and energy-efficient cooling systems (Goger, 2013:78). M\&S linked its suppliers to specific environmental consultants, provided feedback on factory layouts and offered small seed funding to one of the factories - but in general the cost of investment was borne mainly by the local investors. M\&S offered an exclusive buying agreement to one of the plants, but not the other. The third plant was built without a formal partnership with the buyer. While the environmental impacts in internal operations in these factories have been clearly positive (in terms of energy and water use, GHG emissions and ratio of waste to landfill), there has been limited transmission of environmental upgrading upstream to their own suppliers, with the exception of limited purchasing of Better Cotton Initiative licensed cotton and organic textiles (Lund-Thomsen et al., 2018).

Goger (2013) reported that no price premia were offered for garments produced in green factories in Sri Lanka, and that suppliers have come to question the business rationale of their investment in environmental upgrading. They managed to reduce costs (on energy, waste 
disposal, water) and improve productivity and efficiency through organizational change. However, they had yet to fully recoup their initial investment at the time of Goger's fieldwork - something they had expected to have achieved by then. When suppliers became involved in this process, they were looking for additional competitive advantage in a risky and unstable industry that had already led to the consolidation of the supply base. They now argued that while buyers benefited from building their 'green image', these gains were not adequately shared with suppliers.

Similarly, Khattak et al. (2015) show that the achievement of lower operational costs through environmental upgrading of garment factories in Sri Lanka has been accompanied by consistent orders, knowledge spill-overs and enhanced reputation - all positive outcomes (see also Khattak \& Pinto, 2018). However, environmental upgrading did not lead to higher prices from buyers and entailed extra financial costs for suppliers - meaning that supplier profitability overall did not improve. In other words, suppliers need to deliver environmental upgrading to remain in the game. Analogous trajectories have been reported in the garment GVC in Turkey (Tokatli et al., 2008; Tokatli, 2012) and the sporting goods GVC in Pakistan (Khattak and Stringer, 2017). As environmental upgrading becomes more widespread, early movers are losing their competitive advantage. This suggests the working of a 'green Shumpeterian cycle' (Goger, 2013) and the fallacy of composition in environmental upgrading (Milberg and Winkler, 2013).

In sum, on the one hand, the literature suggests that through environmental upgrading suppliers can improve their production processes, leading to operational efficiency through reduction of waste, optimization of resource use, and cost savings. Compliance with local environment regulations, as well as with the environmental requirements of their buyers, may also minimize the risk of receiving financial penalties, fines or order cancellations. When 
these outcomes take place, suppliers are more likely to perceive that their relationships with buyers have strengthened and will continue in the long-term, and that they are improving their competitive advantage. On the other hand, the literature highlights that the purchasing practices of lead firms can make environmental upgrading more difficult for suppliers to undertake. Global buyers claim that consumers are unwilling to pay for environmental improvements at the production level, which means that the drive to lower costs takes precedence over the profitability of suppliers. Indeed, many suppliers do not see the business case of environmental upgrading, given that most buyers do not offer purchase commitments or other incentives. The literature overall suggests that suppliers often engage in environmental upgrading to simply remain in the game, and that production cost reductions provide justifications for buyers to maintain or even further reduce prices, leading to a 'sustainability supplier squeeze' (Ponte, 2019). Additionally, most suppliers that can deliver environmental upgrading are larger in scale and already have superior capabilities in place. This tends to further consolidate the supplier base and marginalize small and medium enterprises (Khan, 2017). In the next section, we contextualize our discussion of environmental upgrading with reference to the Pakistani apparel sector.

\section{Background on the Pakistani Apparel Sector}

Textile and apparel constitute the largest industrial sector of Pakistan and contribute significantly to its economy. It accounts for $8.5 \%$ of GDP, employs $40 \%$ of the industrial labor force, and represents $60 \%$ of national exports and $25 \%$ of industrial value addition (Ministry of Finance, 2018). Apparel alone accounts for approximately 5,000 industrial units and employs $73 \%$ of skilled labor in the textile and apparel sector (Khawar et al., 2019; Trade Development Authority of Pakistan, 2018). Apparel operations are concentrated in two 
provinces (Sindh and Punjab) and are clustered in four cities: Karachi (Sindh), Lahore (Punjab), Faisalabad (Punjab) and Sialkot (Punjab). Each cluster specializes in specific products: denim garments are mainly produced in Lahore, hosiery in Faisalabad, sportswear in Sialkot, and readymade garments in Karachi (Khawar et al., 2019). Exports in the Sialkot cluster are concentrated in the large-scale sector and consist of semi-technical garments with average export prices above $\$ 10$. Karachi specializes in woven garments in the $\$ 5-10$ unit price range, whereas Faisalabad produces knitwear garments in the range of $\$ 1-5$. Firms in Lahore mainly focus on woven garments in the \$5-10 range as well as knitwear (\$1-5), even though during the 1980s and 1990s manufacturing units in Lahore were the most modern, large and vertically-integrated (Hussain et al., 2013; Memon, 2009; Sandhu, 2011).

Ninety per cent of the firms in Karachi have access to workforce training facilities, while only $65 \%$ firms in Sialkot and less than $40 \%$ in Lahore and Faisalabad do so. Despite having the comparative advantage of being the main sea port of Pakistan, the deteriorating security environment has reduced the competitiveness of the Karachi cluster, whereas Lahore and Faisalabad are affected mainly by high energy costs and a lack of skilled labor (Hussain et al., 2013). Production is organized in a large-scale and relatively well-organized segment and a disjointed SME segment. Overall, there is relatively limited investment in the apparel sector and little collaboration between the eight national trade associations that represent the textile and apparel manufacturers of Pakistan (Ministry of Textile Industry, 2014).

Despite weak international competitiveness and high domestic operating costs (Memon, 2016; Khawar, Mukhtar, Javaid, \& Javed, 2019), apparel suppliers have actually engaged in environmental upgrading, including the implementation of environmental management systems. The Pakistan Environmental Protection Agency (PEPA) is in practice unable to enforce the Pakistan Environmental Protection Act of 1997 within the manufacturing sector - 
due to political interference, poor management and lack of technical skills among the personnel deployed within the industrial zones (Sanchez-Triana, Ortolano, \& Afzal, 2012). Yet, a survey conducted by PEPA in 2002 shows that most large-scale apparel exporters are actually compliant with the environmental components of the PEPA Act. This happens because global buyers require their suppliers to be compliant with both Pakistan's as well as their own country's environmental regulations - for example, they ban the use of chemicals such as Azo dyes which are illegal in the EU and the US. The total number of ISO 14001 certifications in Pakistan has also increased, from 26 in the early 2000 s to 314 in the early 2010s (ISO, 2014). Therefore, while environmental upgrading is taking place among suppliers in Pakistan, their share of world apparel exports is declining.

[Table 2 here]

It is primarily large-scale suppliers that are engaging in environmental upgrading in the apparel sector of Pakistan (see Table 2). In term of primary markets, the suppliers in Lahore mainly manufacture for US buyers (only two suppliers also have EU buyers) whereas suppliers in the Faisalabad and Karachi clusters sell to different markets. In Faisalabad, suppliers sell to up to 100 different buyers, while in the other clusters the number of buyers is more limited (up to 30). The length of key buyer-supplier relationships is fairly similar in all clusters (most averaging 8-10 years) and based on contracts; only three suppliers in the Lahore cluster had a strategic alliance/joint venture with a key buyer. These cluster characteristics have important implications for the drivers, processes and outcomes of 
environmental upgrading in the apparel sector of Pakistan, which we explore in the next section.

\section{Environmental Upgrading among Pakistani Apparel Suppliers}

In this section, we discuss the empirical findings of our study under the headings of drivers, processes, and economic outcomes of environmental upgrading. These are the main themes that emerged both in the existing literature and from our analysis of the fieldwork material. Due to space restrictions, we cover the drivers of environmental upgrading only briefly and focus primarily on processes and outcomes.

\subsection{Drivers}

Our research suggests that lead firms primarily focus on environmental improvements in production processes in order to engage their suppliers in environmental upgrading. Buyers do not provide any technical or financial support for environmental upgrading to any supplier, not even their strategic partners. Instead, they rely upon standards, codes of conduct and certification bodies (see section 5.2) to drive the environmental upgrading of their suppliers. Buyers have limited environmental expertise themselves and thus have little handson involvement with their suppliers. Certification bodies are the main tools used by lead firms for improving the 'eco-efficiencies' (De Marchi et al., 2013b) of their suppliers and utilize them extensively for reducing the systematic environmental impacts within their value chains. This 'shallow engagement' (Jeppesen and Hansen, 2004) driving strategy of the lead firm was consistent for all of its suppliers, irrespective of the geographic cluster. 'External' factors (Tewari and Pillai, 2005; Poulsen et al., 2016; Poulsen et al., 2018) are thus driving environmental upgrading within apparel GVC in Pakistan. Buyers face civil society pressures, reputational risks and changing regulatory environments of their home markets. 
However, supplier engagement is primarily buyer-driven and does not on account of local PEPA regulations.

The export-oriented industry is compliant not because they have more environmental consciousness but because the markets and buyers they serve require it. Suppliers have to go for this otherwise they will be uncompetitive and will not have access to those markets, so they are mostly environment compliant. (RB1)

In fact, a trend of proactive upgrading of suppliers is observed in Pakistan as suppliers have realized the importance of environmentally-friendly practices in order to participate in the GVC of large international brands. Therefore, they proactively engage in environmental upgrading to qualify for a business relationship with potential buyers: "We have not been asked to get these carbon certifications, but we are working on it ourselves. We can see that in the next few years' time it will become a requirement" (Interview S5). This strategic choice of complying with future environmental requirements shows that some suppliers are leveraging their environmental upgrading for competitive access to new buyers and markets.

\subsection{Processes}

Environmental upgrading can be seen as a process through which actors modify or alter production systems and practices that result in positive environmental outcomes or the reduction of negative ones. Apparel suppliers in Pakistan upgrade mainly through the acquisition of environmental certifications. Suppliers are actively seeking compliance with environmental standards that can be broadly classified into third-party certifications and buyer codes of conduct. Third-party standards are drafted by autonomous international institutions, both governmental such as the European Union and non-governmental such as the ISO ), World Wildlife Fund(WWF), and the United States Green Business Council (USGBC). Supplier compliance to such standards is verified by independent certification 
bodies, such as Société Générale de Surveillance (SGS), Intertek and Bureau Veritas. Some third party standards such as Registration, Evaluation, Authorization and Restriction of Chemicals (REACH), Global Recycle Standard (GRS), Better Cotton Initiative, ISO 14001 and Leadership in Energy and Environmental Designs (LEED) focus exclusively on environmental issues. Others, such as Worldwide Responsible Accredited Production (WRAP), Sedex, and FairTrade focus primarily on social issues but also encompass some environmental guidelines. The third party certifications obtained by the apparel suppliers of Pakistan are exhibited in Figure 1, while their environmental aspects are detailed in Table 3. Oeko-Tex is the most popular certification, followed by WRAP and ISO 14001. No supplier was LEED certified at the time of fieldwork, and only one (S15) planned to establish an ecobuilding. EU buyers prefer their suppliers to be verified by SGS and to comply to SEDEX, while US buyers prefer WRAP.

[Figure 1 here]

[Table 3 here]

Buyers' codes of conduct provide comprehensive guidelines for suppliers on social, environmental, legal, and ethical, aspects of their business (see Table 4). Codes of conduct normally include environmental issues as important components, which exhibit a high degree of similarity (see Table 5). Environmental standards include protocols for labeling and handling toxic industrial compounds such as polychlorinated biphenyls (PCB), asbestos, alkyl phenol ethoxylates (APEOs), and heavy metals. These guide suppliers on containment of hazardous waste materials, managing spillage and leakages, treatment of waste water by setting up effluent treatment plants (ETP), and sludge disposal - particularly for the suppliers 
involved in wet processing. These codes also cover air emissions, noise, energy conservation, and the management of solid waste - as well as employee training on use of protective equipment and environmental issues. Verification of suppliers is carried out either by buyers themselves or is outsourced to external auditors. Suppliers are awarded color-coded ratings of red for incompliant, yellow for compliant but improvements needed, and green for compliant with environmental standards. In the case of red and yellow ratings, suppliers are given a time frame to rectify the objections and be re-audited. Buyers rarely maintain a supply relationship with suppliers with a red rating, but often compromise with those having a yellow rating. Larger suppliers normally seek both third-party certifications and compliance with the codes of conduct of buyers - often through the same certification body. Four suppliers (S14, S15, S17 and S18) did not hold any third-party environmental certification, yet all 21 suppliers were compliant to the environmental requirements of their buyers' codes of conduct.

[Tables 4 and 5 here]

Environmental upgrading requires suppliers to alter their organizational structures, communication systems, production processes and management styles, and gradually transforms employee mindsets and organizational culture. Larger-scale suppliers hire consultants to guide them in creating these new environmental management systems. Buyers utilize certification bodies extensively for the environmental monitoring of suppliers. This is because certifiers now possess more technical and environmental expertise than buyers themselves. For codes of conduct verification, suppliers are audited on an annual basis. Certification bodies thus occupy a central role in the environmental upgrading of suppliers, 
and suppliers perceive them to be more stringent than actual buyers. Auditors exercise power over suppliers because what they report ultimately determines whether suppliers can enter or remain in a value chain.

The main difference is in the way they are conducting these audits which has become tougher ... The stringency in the rules has come in such a way that before they used to come for a day, and now the auditors come and stay at our company for three days ... and even look at the CCTV tapes. So, the regulations were there even ten years ago but now the audits and monitoring mechanisms have become very stringent. Before, they used to have more tolerance, they used to give us time for corrective actions. Now the monitoring mechanism has become very strict. Such issues in the past used to only impact our business, but now they determine whether you can even do business at all. (S1)

This quote suggests that, in the aftermath of the Rana Plaza collapse in Bangladesh in 2013 (Fitch \& Ferdous, 2014), monitoring and control mechanisms of buyers have changed - there has been an increase in the number of audits (also those unannounced) and these audits have become more meticulous.

\subsection{Economic Outcomes}

Buyers perceive that environmental upgrading benefits suppliers through costs savings. However, suppliers do not associate cost savings with environmental upgrading to the same extent. Instead, they report a variety of net costs in addition to implementation costs - such as those related to certification, auditing, consultancy fees, and product testing. Not surprisingly, these costs are most challenging for the SMEs to shoulder. All suppliers highlighted that certification costs and audit costs are the most cumbersome aspects of environmental upgrading. On average, a third-party certification, excluding the cost of audits, has a price tag between $\$ 1,000$ and $\$ 4,000$ per year, with prices rising annually. Lead firms do not explicitly demand suppliers to obtain third-party environmental certifications such as ISO 14001, but our interviews with factory managers clearly suggest that buyers prefer to source from 
suppliers holding third-party certifications. Therefore, suppliers have started using such certifications to market themselves to potential buyers.

The main reason we go for ISO 14001 is not because buyers demand it but because we use that certification to attract potential buyers, to show buyers that we have a proper environmental management system. And it primarily helps in documentation since when we go for their [codes of conduct] certification we already have all the relevant documentation in place that their auditors may require. (S21)

However, these third-party certifications per se are not sufficient to warrant compliance with buyers' codes of conduct, thus certified suppliers also have to go through multiple verification processes for the environmental components of buyers' codes of conduct. Suppliers thus end up paying several times for verifying the same environmental requirement, often by the same certification body. Codes of conduct compliance audits are more expensive than those for third party certifications because they take up much more time, effort and financial resources from suppliers. Auditors visit the facilities for several days and mid-level management is constantly engaged with them during that time.

The costs [of audits] are very high ... . Most of the audits are client based so they come up to more than a hundred audits in a year. The average cost of an audit is from $\$ 1200$ - \$1500, so if it is 100 audits it costs a lot of money. (S4)

When we audit them, the suppliers are paying for the audit. Every year they have to go through the audit and they have to pay for it. There are surprise audits as well, for that we pay, but for the annual audits the suppliers have to pay. It [audit] is very expensive $\$ 10,000$ - $\$ 15,000$ per audit and it takes 6 days to do. (Buyer B)

Suppliers are sometimes required by the buyers to attend trainings and seminars - on the latest production machinery, on changes in codes of conduct, changes in third party standards, and on new production processes. A code of conduct-related training is usually free, but the other kinds are paid by suppliers.

Sometimes WRAP and BSCI accreditation bodies announce training courses and we get requirements from buyers to attend these trainings to find out what new things are being introduced. For example, after the fire incidents WRAP started doing sessions on first aid, so almost every buyer told us to attend those sessions. We have to pay for these courses out of our pockets. (S12) 
In general, buyers portray environmental upgrading in benign language - as if it were obviously beneficial for suppliers.

I think the benefit of compliance is for no one else other than the suppliers themselves. It will benefit the employees of the company. It will benefit the long-term sustainability of that organization ... [However, suppliers think] it is probably benefiting the final customer or the brand for which they [suppliers] are working. All these compliances are benefiting the people and the organizations that are implementing them. (Buyer A)

Environmental upgrading efforts are seen in a much less benign perspective from the viewpoint of factory managers, who often think buyers are not necessarily motivated by a wish to improve the state of the environment, but instead are concerned about their own brand reputation and seek to avoid negative press.

These buyers are asking us environmental requirements because the markets they serve are sensitive to environmental issues ... So, these companies [have us] engage in these audits and compliance processes in order to save themselves in front of their customers. If any incident occurs in their supply chains and the media highlights their brand involvement, such as in the cases of Tazreen and Rana Plaza, then these brands face a lot of pressure in their home markets. They will have to pay compensation, fines and face lawsuits as they have proper consumer acts in their own countries and will have to face legal matters there. (S9)

Our customers are mostly concerned with the production phase. For example, they have not asked for any requirements for recycling or packaging so far ... They are mainly concerned with the actual product because that is going onto the shelves. (S12)

From the perspective of factory managers, the financial outcomes of environmental upgrading are limited. Their financial sustainability is mainly related to obtaining large orders based on offering better product quality and lower prices, not on environmental performance. This suggests that environmental upgrading does not necessarily or even regularly generate economic rents. Widespread conformity by suppliers in the Global South and the unwillingness of buyers to pay competitive prices for environmental compliance have eroded the possible rents that early-movers may have enjoyed in the past. These observations are 
similar to those reported in the apparel GVC in Sri Lanka (Goger, 2013; Khattak et al., 2015) and Turkey (Tokatli et al., 2008; Tokatli, 2012), and the sporting goods GVC in Pakistan (Khattak and Stringer, 2017). As all suppliers deliver similar standards of environmental compliance and embed eco-friendly practices in their operations, their environmental upgrading can no longer afford them the leverage to get a price premium for the garments they produce. Suppliers need to deliver environmental upgrading to remain in the game.

Nevertheless, factory managers also recognize that environmental upgrading improves the possibility of new market access, generates word of mouth reputational enhancements and may offer relational outcomes by affecting their buyer supplier relationships. These relational outcomes were mentioned by a few large scale suppliers, who perceive that environmental upgrading increases the levels of trust, understanding and confidence between them and their buyers. This implies that environmental upgrading may offer business continuity with the buyers. These positive outcomes are similar to those reported in Sri Lanka where environmental upgrading of apparel factories was accompanied by consistent orders, knowledge spill-overs and enhanced reputation (Khattak \& Pinto, 2018).

\section{The Factory Manager Dilemma}

In the Pakistani apparel value chain, local factory managers mainly see environmental upgrading as an exercise they have to engage in, to assist lead firms in their reputation and risk management efforts. They also draw attention to how buyer purchasing practices tend to undermine their very same environmental upgrading efforts. Factory managers often mention the double standards practiced by international buyers - who preach the need for suppliers to engage in environmental upgrading, while at the same time are unwilling to financially assist them in these processes. 
You do not get better prices because you are compliant ... Not a single customer has given us any price-related benefits for environmental compliance. [Buyer C] is pretty serious on reducing carbon emissions and they come and tell us to reduce our footprint. Even [Buyer D] does this. So, we work on it but do not get anything in return. (S11)

Factory managers perceive environmental upgrading mainly as a challenge because it requires investment in capital assets, technology, certifications, system modifications, and training of human resources, all to be done in the absence of price incentives or other forms of financial support. Yet, global buyers frame their interaction with suppliers in Pakistan as long-term, strategic partnerships: 'We are committed to such [compliant] suppliers for the next two-three years. When we work with someone, we do it for the long term ...so we have systems' (Buyer B). Factory managers concur that environmental upgrading can build up mutual expectations in view of building longer-term commercial relationships, but they also emphasize that there is no direct legal obligation for buyers to honor these partnerships: 'There is an implied alliance if you have compliance but there is no contractual binding on that. Once you are compliant, you both are important for each other' (S10).

In fact, the term 'strategic partnership' does not involve partnering in terms of equally sharing financial costs and benefits, nor does it translate into strategic alliances or joint ventures (see Table 2). As such, the term 'partnership' does not have much meaning or relevance in the eyes of some factory managers.

Even when they call us partners, I kind of laugh at it because partnership is where both parties are equal but here it is never like that ... If they are being very unreasonable, yes you can talk to them, but normally factories and suppliers cannot win. This is a problem in this business - you generally do not have that many rights ... We can have a strategic alliance, but you know they are not very loyal when it comes to price ... they can lower prices but they will still tell you that you are their partner and that they have a three-year plan with you. (S5) 
Suppliers report unreasonable environmental requirements from buyers - including difficult clauses in contracts seeking to reduce buyer liability in case of mishaps. They also complain of buyers overlooking compliance in other countries where prices are extremely cheap.

I would say that in case of [Buyer D], their compliance advisors are weak. Two years back, they demanded that emergency exits must have push bars and they kept saying that we will not do business with suppliers otherwise. [We did that] and then six months ago, they stopped buying from us. (S3)

In terms of sourcing practices, such as price negotiations and collaboration in production processes, no major difference is found between buyers, even though two of them position themselves in consumer markets through their environmental sustainability initiatives. This suggests that all buyers prioritize their own financial goals over environmental impact in their global sourcing. This mirrors findings in the social upgrading literature where buyers claim that they seek to engage in collaboration and long-term trading relationships with their strategic partners, but are mainly driven by price pressure and changes in seasonal demand which tend to results in decent work 'deficit' in local export factories (Lund-Thomsen and Lindgreen, 2018).

We conclude that engaging in environmental upgrading has become necessary for local suppliers to secure and maintain access to GVCs. This generates reputation enhancement for lead firms but undermines the financial viability of suppliers. In other words, Global South suppliers are required to both absorb the consequences of global buyers' unsustainable purchasing practices and reduce their own profitability - all in the name of sustainability.

\section{Conclusion}

The GVC literature has made substantial progress in explaining how economic and social upgrading processes affect suppliers and workers in the Global South who are engaged in 
GVCs. However, we know much less on how environmental upgrading efforts affect the economic viability of these suppliers. To partially fill this gap, in this article we examined how environmental upgrading practices influence buyer-supplier relations in the apparel industry of Pakistan. We highlighted the presence of a 'factory manager dilemma' to document the trade-offs suppliers face in having to deal with both environmental upgrading requirements and the everyday purchasing practices of their buyers.

Our analysis reveals that factory managers mainly see environmental upgrading as an instrument of reputation and risk management that lead firms employ, and that suppliers pay the cost for. Although some suppliers highlight the potential for cost savings arising from environmental management systems, they generally report increasing costs that do not match these benefits. They argue that the everyday purchasing practices of their buyers, such as the squeezing of prices and the unwillingness to engage in cost-sharing of environmental upgrading efforts, indicate a double standard. Buyers are not willing to accept their share of financial responsibility for enabling suppliers to actually upgrade. Furthermore, they expose suppliers to unstable demand, lower unit prices and last-minute changes in order volumes and specifications. Environmental upgrading for suppliers has become necessary to secure and maintain access to GVCs. But in order to do so, suppliers reduce their own profitability in the name of sustainability.

Analytically and empirically, in this article we provided three novel contributions to the literature on upgrading: (1) we disentangled environmental upgrading as a process from the economic outcomes of upgrading and distinguished between the costs and benefits accruing to lead firms and those accruing to their suppliers (as called for by Krishnan, 2017b); (2) we highlighted the limitations of upgrading that arise from the 'green Schumpeterian cycle' and the fallacy of composition - indicating how early movers in environmental upgrading may 
lose their competitive advantage as other actors embark on the same trajectories; and (3) we supplied new evidence that lead firms in GVCs not only leverage environmental issues for risk management purposes, but also successfully extract 'green value' from their suppliers based in the Global South (see also Goger, 2013; Khattak et al. 205; Ponte, 2019). While environmental upgrading of suppliers in the Global North can indeed include paths leading to better environmental practices and enhanced profitability through lowering costs and improving efficiency (de Marchi et al. 2013a, 2013b), this is much rarer among suppliers in the Global South. These suppliers may indeed take pro-active strategies to environmentally upgrade. But in the context of surviving in an increasingly competitive supplier field, they fail to generate economic rent - suggesting paths that Kaplinsky (2005) would have termed 'immiserizing green growth'.

\section{References}

Bair, J. (2009). Global commodity chains: genealogy and review. In: Bair (ed.) Frontiers of Commodity Chain Research. Stanford: Stanford University Press, pp. 1-34.

Barrientos, S. (2019). Changing Gender Patterns of Work in Global Value Chains: Capturing the Gains, Cambridge University Press, Cambridge.

Barrientos, S., Gereffi, G. \& Rossi, A. (2010). Economic and social upgrading in global production networks: Developing a framework for analysis. International Labor Review, 150, 319-340.

Barrientos, S., Knorringa, P., Evers, B., Visser, M., \& Opondo, M. (2016). Shifting regional dynamics of global value chains: Implications for economic and social upgrading in African horticulture, Environment and Planning A, 48(7), 1266-83.

Barrientos, S. \& Visser, M. (2013). South African horticulture: Opportunities and challenges for economic and social upgrading in value chains. Capturing the Gains Working Paper 12. Manchester: University of Manchester.

Bernhardt, T. \& Pollak, R. (2016). Economic and social upgrading dynamics in global manufacturing value chains: A comparative analysis. Environment and Planning A, $48,1220-1243$.

Blažek, J. (2015). Towards a typology of repositioning strategies of GVC/GPN suppliers: The case of functional upgrading and downgrading. Journal of Economic Geography, $16,849-869$. 
Blowfield, M., \& Frynas, J. G. (2005). Editorial - Setting new agendas: critical perspectives on Corporate Social Responsibility in the developing world. International Affairs, 81(3), 499-513.

Brewer, B. D. (2011). Global commodity chains and world income inequalities: The missing link of inequality and the upgrading paradox. Journal of World-Systems Research, 17, 308-327.

Coe, N. M. \& Hess, M. (2013). Global production networks, labour and development. Geoforum, 44, 4-9.

Coe, N. M. \& Yeung, H. W.-C. (2015). Global Production Networks: Theorizing Economic Development in an Interconnected World. Oxford: Oxford University Press.

De Marchi, V., Maria, E., \& Micelli, S. (2013). Environmental strategies, upgrading and competitive advantage in global value chains. Business Strategy and the Environment, 22(1), 62-72.

De Marchi, V., Maria, E., \& Ponte, S. (2013). The greening of global value chains: Insights from the furniture industry. Competition \& Change, 17(4), 299-318.

Fitch, N., \& Ferdous, I. (2014). The Deadly Cost of Fashion. New York Times, New York, April 14.

Gereffi, G., Humphrey, J., \& Sturgeon, T. (2005). The governance of global value chains. Review of International Political Economy, 12(1), 78-104.

Gereffi, G. \& Lee, J. (2012). Why the world suddenly cares about global supply chains. Journal of Supply Chain Management, 48, 24-32.

Glückler, J. \& Panitz, R. (2016). Relational upgrading in global value networks. Journal of Economic Geography, 16, 1161-1185.

Goger, A. (2013). The making of a 'business case' for environmental upgrading: Sri Lanka's eco-factories. Geoforum, 47, 73-83.

Golini, R., De Marchi, V., Boffelli, A., \& Kalchschmidt, M. (2018). Which governance structures drive economic, environmental, and social upgrading? A quantitative analysis in the assembly industries. International Journal of Production Economics, 203, 13-23.

Hussain, S. T., Malik, K., Khan, M. U., Faheem, A., Nabi, I., \& Hamid, N. (2013). A comparative analysis of the garments sector of Pakistan. SSRN 3117709.

International Trade Centre. (2019). Trade statistics for international business development, ITC: Geneva.

ISO. (2014). The ISO Survey of Certications 2014, ISO, Geneva.

Ivarsson, I., \& Alvstam, C. G. (2010). Supplier Upgrading in the Home-furnishing Value Chain: An Empirical Study of IKEA's Sourcing in China and South East Asia. World Development, 38(11), 1575-1587.

Ivarsson, I., \& Alvstam, C. G. (2011). Upgrading in global value-chains: a case study of technology-learning among IKEA-suppliers in China and Southeast Asia. Journal of Economic Geography, 11(4), 731-752.

Jeppesen, S. \& Hansen, M. W. (2004). Environmental upgrading of Third World enterprises through linkages to transnational corporations. Theoretical perspectives and preliminary evidence. Business Strategy and the Environment, 13(4), 261-274. 
Kaplinsky, R. (2005).Globalization, Poverty and Inequality: Between a Rock and a Hard Place. Oxford: Blackwell Publishers.

Khan, FR., Lund-Thomsen, P. (2011). CSR as imperialism - towards a phenomenological approach to CSR in the developing world, Journal of Change Management, 11(1), 7390.

Khan, M. J. (2017). An exploratory evidence of the types of challenges and opportunities perceived by the small and medium enterprises in the apparel export sector of Pakistan. Abasyn University Journal of Social Sciences, 10(2), 373-395.

Khattak, A., \& Pinto, L. (2018). A Systematic Literature Review of the Environmental Upgrading in Global Value Chains and Future Research Agenda. Journal of Distribution Science, 16, 11-19.

Khattak, A., \& Stringer, C. (2017). Environmental upgrading in Pakistan's sporting goods industry in global value chains: A question of progress? Business \& Economic Review, 9(1), 43-64.

Khattak, A., Stringer, C., Benson-Rea, M., \& Haworth, N. (2015). Environmental upgrading of apparel firms in global value chains: Evidence from Sri Lanka. Competition \& Change, 19(4), 317-335.

Khawar, H., Mukhtar, N., Javaid, M., \& Javed, U. (2019). Pakistan's Readymade Garments Sector: Challenges and Opportunities. Pakistan Business Council, Karachi.

Krishnan, A. (2017a). The origin and expansion of regional value chains: The case of Kenyan horticulture. Global Networks, 18(2), 238-263.

Krishnan, A. (2017b). Re-thinking the environmental dimensions of upgrading and embeddedness in production networks: The case of Kenyan horticulture farmers. $\mathrm{PhD}$, University of Manchester, UK.

Lister, J., Poulsen, R. T. \& Ponte, S. (2015). Orchestrating transnational environmental governance in maritime shipping. Global Environmental Change, 34, 185-195.

Locke, R. M., Rissing, B. A. \& Pal, T. (2013). Complements or substitutes? Private codes, state regulation and the enforcement of labour standards in global supply chains. British Journal of Industrial Relations, 51(3), 519-552.

Lund-Thomsen, P. (2004). Towards a critical framework on corporate social and environmental responsibility in the South: the case of Pakistan, Development, 47(3), 106-113.

Lund-Thomsen, P. \& Nadvi, K. (2010). Global value chains, local collective action and corporate social responsibility: A review of empirical evidence. Business Strategy and the Environment, 19(1), 1-13.

Lund-Thomsen, P., \& Lindgreen, A. (2014). Corporate social responsibility in global value chains: Where are we now and where are we going? Journal of Business Ethics, 123(1), 11-22.

Lund-Thomsen, P., \& Lindgreen, A. (2018). Is there a sweet spot in ethical trade? A critical appraisal of the potential for aligning buyer, supplier and worker interests in global production networks, Geoforum, 90, 84-90.

Lund-Thomsen, P., Coe, N., Sing, S., \& Riisgaard, L. (2018). Bridging global standard requirements and local farmer needs: Implementing partners of the Better Cotton 
Initiative in Pakistan and India. CBDS Working Paper 1/2018, Copenhagen Business School.

Memon, N. (2009). Knitwear Industry - Radical reforms needed to achieve \$ 2.5 billion exports Pakistan Textile Journal, January.

Memon, N. (2016). Pakistan apparel industry: Competing global market. Pakistan Textile Journal (January), 33-35.

Milberg, W., \& Winkler, D. (2013). Outsourcing Economics: Global Value Chains in Capitalist Development. Cambridge: Cambridge University Press.

Ministry of Commerce (Pakistan). (2003). Trade Policy of Pakistan 2003-04, Ministry of Commerce, Islamabad.

Ministry of Finance (Pakistan). (2018). Pakistan Economic Survey 2017-18, Ministry of Finance, Islamabad

Ministry of Textile Industry (Pakistan). (2014), Yearbook 2010-11 and 2011-12, Ministry of Textile Industry, Islamabad.

Morris, M. \& Staritz, C. (2014). Industrialization trajectories in Madagascar's export apparel industry: ownership, embeddedness, markets and upgrading. World Development, 56, 243-257.

Nadvi, K., \& Raj-Reichert, G. (2015). Governing health and safety at lower tiers of the computer industry global value chain. Regulation \& Governance, 9(3), 243-258.

Neilson, J., Wright, J. \& Aklimawati, L. (2018). Geographical indications and value capture in the Indonesian coffee sector. Journal of Rural Studies, 59, 35-48.

O'Rourke, D. (2006). Multi-stakeholder regulation: Privatizing or socializing global labor standards? World Development, 34(5), 899-918.

Pegler, L. (2015). Peasant inclusion in global value chains: Economic upgrading but social downgrading in labour processes? Journal of Peasant Studies, 42(5), 929-956.

Ponte, S. (2019). Business, Power and Sustainability in a World of Global Value Chains. London: Zed Books.

Posthuma, A. (2010). Beyond 'regulatory enclaves': Challenges and opportunities to promote decent work in global production networks. In: Nathan, D. (ed.) Labour in Global Production Networks in India. Oxford: Oxford University Press.

Poulsen, R. T., Ponte, S. \& Lister, J. (2016). Buyer-driven greening? Cargo-owners and environmental upgrading in maritime shipping. Geoforum, 68, 57-68.

Poulsen, R. T., Ponte, S. \& Sornn-Friese, H. (2018). Environmental upgrading in global value chains: The potential and limitations of ports in the greening of maritime transport. Geoforum, 89, 83-95.

Raj-Reichert, G. (2013). Safeguarding labour in distant factories: Health and safety governance in an electronics global production network. Geoforum, 44, 23-31.

Ruwanpura, K. N., \& Wrigley, N. (2011). The costs of compliance? Views of Sri Lankan apparel manufacturers in times of global economic crisis. Journal of Economic Geography, 11(6), 1031-1049.

Ruwanpura, K.N., (2016). Scripted Performances? Local Readings of 'Global' Health and Safety Standards in the Apparel Sector in Sri Lanka. In Labour in Global Value 
Chains in Asia, Nathan, D., Tewari, M. \& Sarkar, S. (eds.). Cambridge: Cambridge University Press, p. 265-286.

Sanchez-Triana, E., Ortolano, L., \& Afzal, J. (2012). Green Industrial Growth:

Mainstreaming Environmental Sustainability in Pakistan's Industrial Sector. World Bank, Washington D.C.

Sandhu, K. (2011). Challenges to Pakistan's Value Added Industry: Pakistan Readymade

Garments. Paper presented at the 3rd International Conference on Textile and Clothing, Lahore, Pakistan.

Schmitz, H. (2006). Learning and earning in global garment and footwear chains. European Journal of Development Research, 18(4), 546-571.

Tewari, M., \& Pillai, P. (2005). Global standards and the dynamics of environmental compliance in India's leather industry. Oxford Development Studies, 33(2), 245-267.

Tokatli, N. (2012). Toward a better understanding of the apparel industry: A critique of the upgrading literature. Journal of Economic Geography, 13(6), 993-1011.

Tokatli, N., Wrigley, N., \& Kizilgün, Ö. (2008). Shifting global supply networks and fast fashion: Made in Turkey for Marks \& Spencer. Global Networks, 8(3), 261-280.

Trade Development Authority of Pakistan. (2014). Pakistan's Trade Statistics 2014-15, TDAP, Islamabad.

Trade Development Authority of Pakistan. (2018). Pakistan Trade Statistics 2017-18, TDAP, Islamabad

WTO. (2014). WTO International Trade Statistics. World Trade Organization, Geneva.

WTO. (2017). World Trade Statistical Review. World Trade Organization, Geneva.

Yeung, H. W.-C. (2016). Strategic Coupling: East Asian Industrial Transformation in the New Global Economy. Ithaca: Cornell University Press.

Yeung, H. W.-C. \& Coe, N. (2015). Toward a dynamic theory of global production networks. Economic Geography, 91(1), 29-58.

\section{Endnotes}

\footnotetext{
${ }^{1}$ Data analysis was carried out in four stages. In the first stage, open coding procedures were used to categorize the interview transcriptions. In the second stage, analytical categories using axial coding procedures were developed. In the third stage, emergent insights and themes were identified using primary and secondary data comparisons. Relevant literature on environmental upgrading in GVCs, in the apparel industry and on GVC governance was examined along with interview material, government reports, and company websites and documentation. During this stage, we also identified three main analytical themes. In the fourth stage, noteworthy quotations from our respondents related to these themes were included in the writing process.

${ }^{2}$ Space limitations do not allow us to analyze the actual environmental outcomes of upgrading in this article.
} 